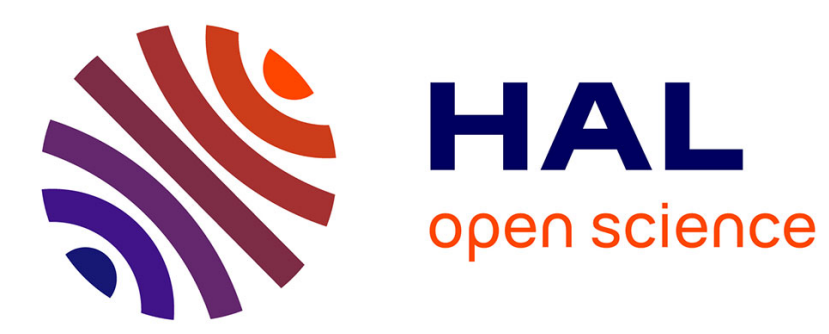

\title{
Urban hydrologic trend analysis based on rainfall and runoff data analysis and conceptual model calibration
}

S. Sun, S. Barraud, F. Branger, Isabelle Braud, H. Castebrunet

\section{To cite this version:}

S. Sun, S. Barraud, F. Branger, Isabelle Braud, H. Castebrunet. Urban hydrologic trend analysis based on rainfall and runoff data analysis and conceptual model calibration. Hydrological Processes, 2017, 31 (6), pp.1349-1359. 10.1002/hyp.11109 . hal-01710641

\section{HAL Id: hal-01710641 \\ https://hal.science/hal-01710641}

Submitted on 26 Feb 2018

HAL is a multi-disciplinary open access archive for the deposit and dissemination of scientific research documents, whether they are published or not. The documents may come from teaching and research institutions in France or abroad, or from public or private research centers.
L'archive ouverte pluridisciplinaire HAL, est destinée au dépôt et à la diffusion de documents scientifiques de niveau recherche, publiés ou non, émanant des établissements d'enseignement et de recherche français ou étrangers, des laboratoires publics ou privés. 
Urban hydrologic trend analysis based on rainfall and runoff data analysis and conceptual model calibration

${ }^{1 *}$ Siao Sun; ${ }^{2}$ Sylvie Barraud; ${ }^{3}$ Flora Branger; ${ }^{3}$ Isabelle Braud; ${ }^{2}$ Hélène Castebrunet

*Corresponding author: suns@igsnrr.ac.cn

${ }^{1}$ Key laboratory of Regional Sustainable Development Modeling, Institute of Geographical Sciences and Natural Resource Research, Chinese Academy of Sciences, Beijing, 100101, People's Republic of China

${ }^{2}$ University of Lyon, INSA Lyon, DEEP, F-69621 Villeurbanne CEDEX, France.

${ }^{3}$ Irstea, UR HHLY, Hydrology-Hydraulics, 5 rue de La Doua, BP 32108,F-69616

Villeurbanne CEDEX, France.

\section{Keywords}

Urban hydrology; urbanization; conceptual rainfall-runoff model; trend analysis; Mann-

Kendall test

\section{Abstract}

Urban stormwater is a major cause of urban flooding and natural water pollution. It is therefore important to assess any hydrologic trends in urban catchments for stormwater management and planning. This study addresses urban hydrological trend analysis by examining trends in variables that characterize hydrological processes. The original and modified Mann-Kendall methods are applied to trend detection in two French catchments, i.e., Chassieu and La Lechere, based on approximately one decade of data from local monitoring programs. In both catchments, no trend is found in the major hydrological process driver (i.e., rainfall variables), whereas increasing trends are detected in runoff flow rates. As a consequence, the runoff coefficients tend to increase during the study period, probably due to growing imperviousness with the local urbanization process. In addition, conceptual urban rainfall-runoff model parameters, which are identified via model calibration with an event 
based approach, are examined. Trend detection results indicate that there is no trend in the time of concentration in Chassieu, whereas a decreasing trend is present in La Lechere, which, however, needs to be validated with additional data. Sensitivity analysis indicates that the original Mann-Kendall method is not sensitive to a few noisy values in the data series.

\section{Introduction}

Urban stormwater is a major cause of urban flooding and water pollution, which can lead to serious economic and social consequences. Currently, it is widely recognized that effects that are closely related to human activities, such as climate change and urbanization can result in significant alteration of stormwater quantity and quality (e.g., Astaraie-Imani et al., 2012). The design and operation of urban storm water projects that aim to reduce the adverse impact of stormwater should take possible changes in urban hydrology patterns into account. It is therefore important to assess any hydrologic trend (if one exists) in urban catchments.

Considerable attention has been paid to trend analysis in research areas in climatology, hydrology and water quality in recent years. Examples of trend detection applications in water resources studies include trend studies of precipitation (e.g., Xu et al., 2003; Partal and Kahya, 2006; Gocic and Trajkovic, 2013), streamflow (e.g., Douglas et al., 2000; Zhang et al., 2001; Burn and Elnur, 2002; Yue et al., 2002; Aziz and Burn, 2006), and river and drainage water quality (Hirsch et al., 1982; Awadallah et al., 2011; Sun et al., 2015). A number of trend detection methods including parametric and non-parametric tests have been applied (Hess et al. 2001). A non-parametric test is generally more suitable for non-normally distributed and censored data, which are frequently encountered in water resources data (Yue et al., 2002). The Mann-Kendall method (Mann, 1945; Kendall, 1955) is one of the most commonly used non-parametric trend detection tests (e.g., Omar et al., 2006). Because the Mann-Kendall method generally requires serial independence, some previous studies have modified the 
Mann-Kendall Method to apply it to data presenting seasonality or serial correlations (e.g.,

Hirsch and Slack, 1984; Hamed and Rao, 1998; Yue et al., 2002).

A rainfall-runoff model that transforms the meteorological forcing (rainfall) into the

hydrological response of a catchment (runoff) is an important tool for theoretical and applied research in hydrology. A simple conceptual rainfall-runoff model can sometimes serve as a powerful tool for aiding in understanding local hydrological processes. For instance, the hydrological response can be linked to landscape attributes by deriving the relationship between hydrological model parameters and landscape attributes (e.g., Post and Jakeman, 1999). Statistically significant correlations between some parameters of a conceptual daily rainfall-runoff model and the catchment physical and climatic characteristics were found (Chiew et al., 2002). Hence, the interpretability of the rainfall-runoff model parameters can possibly shed some light on the hydrologic behaviour of a catchment (Maneta et al., 2007).

Given the importance of assessing hydrologic trend in urban catchments, the main objective of this paper is to present a methodology that identifies and quantifies hydrologic trend. The hydrological trend analysis is addressed using a dual approach, i.e., by analysing both rainfall and runoff data and model parameters identified from the calibration of a conceptual hydrological model. The rationale of examining possible hydrological trends via calibrated hydrological model parameters is that if there is any change in the local hydrologic process, non-stationarity will probably be present in model parameters characterizing the temporal hydrological process. In addition to direct analysis of rainfall and runoff data, a conceptual urban hydrological model helps investigate more characteristics of local hydrology (e.g., initial precipitation losses and the time of concentration), which cannot be measured directly. However, it should be noted that the evolution of hydrological processes is an aggregate result of changes of many distributed factors and processes on smaller scales (than the catchment scale) in local hydrology (e.g., changes in distributed land uses and hydrological properties), 
using a conceptual rainfall-runoff model, this study only addresses the evolution of model parameters that are highly lumped on the catchment scale which reveal the general hydrological responses of urban/peri-urban catchments. The evolution of the hydrological trend provides the most direct evidence of changes in local hydrology and the quantification of the trends in relevant parameters is useful in urban stormwater management. The evolution of processes, factors and properties on smaller scales than the catchment scale is beyond the discussion of this study. This study also provides guidance for analysing long-term hydrological trends by applying temporal calibration of a conceptual hydrological model. The effectiveness of such an approach is demonstrated via applications of the methodology to two French catchments.

\section{Case studies and data}

Two urban catchments in the suburbs of Lyon, France, i.e., the Chassieu catchment and the La Lechere catchment, are studied in this paper. Both catchments are monitoring sites under the OTHU program (www.othu.org), which has been operating for over a decade to improve our knowledge on urban water system management by acquiring reliable data of both wet and dry weather flows and their impacts on the receiving environment.

The Chassieu catchment is located in the east of the Greater Lyon area. It covers an industrial area of 185 ha with an imperviousness coefficient of approximately 0.72 . The catchment is drained by a separate stormwater sewer system, which also receives dry weather flows from cooling of industrial processes (that can be assumed clean). The pervious area is not connected to the sewer system. Rainfall in Chassieu was measured by a tipping-bucket rain gauge installed in the catchment, and a six-minute rainfall time series is available. The catchment runoff flow rate was computed from water depth measurements in the $1.6 \mathrm{~m}$ circular concrete pipe at the outlet of the catchment using the Manning equation (calibrated and validated using measured water depth and velocity data in the pipe) with a two-minute 
interval from 2004 to 2011 . The rainfall and runoff time series suffer from $7.4 \%$ and $13.1 \%$ missing data, respectively.

La Lechere catchment is located to the west of Lyon. The catchment covers a maximum area of 410ha when all of the combined sewer overflows (CSOs) are activated. The land in the catchment is mainly composed of urban areas (53\%), agricultural fields (45\%) and forests (3\%) (Braud et al., 2013). The urban areas are drained by combined sewer networks, with several CSOs connected to the Chaudanne River. The contributing area of stormwater to the combined sewer system is approximately 120 ha (stormwater from other areas are not connected to the sewers). In addition to the CSOs, the Chaudanne River also receives natural flows from rural areas. More details about the catchment can be found in Jankowfsky et al. (2014). Rainfall was measured by a tipping-bucket rain gauge located in the catchment. A one-minute rainfall time series is available with approximately $13.7 \%$ missing data. The runoff flow in the Chaudanne River, mainly composed of CSOs from urban areas and natural streamflow from rural areas, was computed from water depth measurements in the calibrated Parshall flume at a gauge station. The runoff flow data are registered with varied time steps, typically from two minutes to one hour. A two-minute time series was created using a linear interpolation method. $2.8 \%$ of the runoff flow data is missing. Rainfall and flow data are both available from June 2005 to December 2014.

\section{Methodology}

\subsection{Mann-Kendal test and modified Mann-Kendall test}

The Mann-Kendall method is a rank-based nonparametric trend detection test extensively applied in climatology and hydrology. The null hypothesis of the Mann-Kendall test $H_{0}$ states that the data are a sample of $n$ independent and identically distributed random variables, whereas the alternative hypothesis $H_{1}$ is that $x_{k}$ and $x_{j}$ are not from identical distributions $(k, j$ $<=n$ and $k \neq j)$. The test statistic $S$ is defined as: 


$$
S=\sum_{k=1}^{n-1} \sum_{j=k+1}^{n} \operatorname{sgn}\left(x_{j}-x_{k}\right)
$$
where $\operatorname{sgn}(\theta)$ is the sign function that equals $-1,0$ and 1 when $\theta$ is below, equal to and above 0 , respectively. Under the null hypothesis, $S$ is asymptotically normally distributed with the mean of 0 and a constant variance, which is a function of the number of data in a tested data series (e.g., Hess et al., 2001; Gocic and Trajkovic, 2013). A $P$-value, which presents the probability of obtaining samples as extreme as the observed ones, can be computed from given $S$ and its variance. The null hypothesis is accepted with a higher $P$-value than a predefined significance level. Otherwise, the null hypothesis is rejected, suggesting that a trend is detected. Two levels of significance, i.e., $5 \%$ and $1 \%$, are used in this study.

The Mann-Kendall method usually indicates a higher false positive outcome for data with positive autocorrelation, and it is thus no more effective for auto-correlated time series (e.g., Yue et al., 2002). A modified Mann-Kendall trend test (Hamed and Rao, 1998) is used when the autocorrelation effect in a data series is significant. In the modified Mann-Kendall method, the variance of $S$ is calculated using an empirical formula with a multiplicative coefficient, which is a function of the autocorrelation coefficient (see Hamed and Rao, 1998 for the formula). As a trend generally leads to positive autocorrelation, a data series is firstly detrended with a linear trend estimated from linear regression. The detrended data series is then tested for its autocorrelation effect (Yue et al., 2002). If the autocorrelation in a data series is insignificant at the 5\% significance level, the Mann-Kendall test is applied.

Otherwise, the modified Mann-Kendall test is performed.

The slope of a trend (if one exists) can be estimated by a non-parametric index (Sen, 1968) based on the assumption of a linear trend:

$$
\beta=\operatorname{Median}\left(\left(x_{j}-x_{i}\right) /(j-i)\right), \quad i<j
$$


The value of $\beta$ represents the changing value per event if an event-based data series is considered. An annual slope of a trend is computed by multiplying the average number of events in one year to this value.

\subsection{Rainfall and runoff event identification}

Storm events are identified from continuous rainfall time series with a dry period over four hours between two events, which is empirically identified (Métadier and Bertrand-Krajewski, 2012; Sun et al., 2015). This study concerns only urban rapid flow. For most events, the rapid response of runoff to rainfall from urban areas ends in four hours in both catchments according to visual inspection. The time series of runoff is thus identified covering the period of a corresponding rainfall and four hours more after the rainfall event ends. In La Lechere, the measured runoff flows in the Chaudanne River are partly from upstream rural areas, which respond much slower than urban areas. A baseflow, considered as a constant flow with the flow rate equal to the minimum flow rate measured during an event, is subtracted from the measured runoff time series to identify the urban rapid flow part. The baseflow in Chassieu mainly comes from industrial wastewater. For most events, the assumption of a constant baseflow during an event for several hours is reasonable.

Only significant events are considered for trend analysis of urban hydrological processes, as parameters characterizing small events are easily affected by influential factors such as initial rainfall loss, baseflow and measurement uncertainty. Significant events in Chassieu are defined with a total rainfall depth over $1 \mathrm{~mm}$ and duration over 30 minutes. In La Lechere, a higher threshold with $2 \mathrm{~mm}$ rainfall depth and over 30-minute duration is adopted because the CSOs in the combined sewers are often not activated during smaller events. In addition, a significant event in both catchments requires a mean urban runoff flow over $5 \mathrm{~L} / \mathrm{s}$.

\subsection{Simple parameters characterizing hydrological processes}


Two simple parameters that can be directly calculated from rainfall and runoff data without modelling, i.e., the runoff coefficient and lag time, are derived for each event. The runoff coefficient is the ratio of runoff water volume to rainfall volume, arbitrarily representing the proportion of rainfall entering the drainage system, which is generally a function of land covers and imperviousness of the area. Trend analysis of the runoff coefficient of rapid urban runoff can possibly reveal the evolution in local urbanization. The lag time measures the response time of a catchment to a rainfall event, which is closely related to the topography, geology and land use within a catchment. In this study, the lag time of one event is evaluated as the time difference between the mass centres of the hyetograph and the hydrograph.

Evolution of the lag time can possibly reveal changes in mechanisms and processes governing the runoff generation and transportation in a catchment. For instance, the lag time in an area drained with sewer pipes is much shorter than that in a naturally drained area of a comparable size and slope.

\subsection{Conceptual urban rainfall-runoff model}

Noting that the simple parameters defined in the above section are directly calculated from rainfall and runoff data, ignoring the non-linear complex real rainfall-runoff mechanisms may create bias in characterising the local process. Therefore, a conceptual urban rainfall-runoff model is employed in this study to aid in identifying more relevant variables based on a more comprehensive description of the hydrological process.

The conceptual urban rainfall-runoff model consists of a simple rainfall loss model and a routing model of two cascaded linear reservoirs. The evaporation and evapotranspiration are negligible at an event scale, and are thus not considered in the model structure using an eventbased approach. This model has been successfully applied in urban hydrology for small impervious catchments drained by artificial sewer systems (e.g., Sun and Bertrand-Krajewski, 2013; Leonhardt et al., 2014). The rainfall loss model calculates net rainfall $I_{\text {net }}$ by subtracting 

rainfall $I$.

$$
I_{\text {net }}(t)=\left\{\begin{array}{l}
0 \\
I(t)\left(1-P_{\text {cons }}\right)
\end{array}\right.
$$

Net rainfall is shifted with a time shift $\mathrm{T}_{\text {shift }}$ and is converted to inflow by multiplying it by the effective catchment area $A$ :

$Q_{\text {in }}(t)=I_{\text {net }}\left(t-T_{\text {shift }}\right) \times A$

In the runoff routing model, $Q_{\text {in }}$ is routed through two cascaded linear reservoirs with the same reservoir constants $(K)$. A linear reservoir assumes that the outflow $Q_{\text {out }}$ is linearly related to the storage volume. The analytical solution of a linear reservoir model over the time interval $[t-\Delta t, t]$ is

$$
Q_{\text {out }}(t)=\exp \left(-\frac{\Delta t}{K}\right) Q_{\text {out }}(t-\Delta t)+\left[1-\exp \left(-\frac{\Delta t}{K}\right)\right] Q_{\text {in }}(t)
$$

The outflow from the first linear reservoir is then routed to the second reservoir as the inflow and the outflow from the second reservoir is the output of the conceptual model. The conceptual urban hydrological model contains four parameters, i.e., rainfall initial loss $L_{\text {ini }}$, rainfall constant proportional loss $P_{\text {cons }}$, time shift of inflow $T_{\text {shift }}$ and reservoir constant of the two reservoirs $K$.

\subsection{Event-based conceptual hydrological model calibration}

An event-based approach for hydrological process modelling is computationally efficient when runoff is restricted to a short period after a storm event (Maneta et al., 2007). This is 
often the case in urban catchments equipped with storm sewer systems. A conceptual hydrological model is often too simple to cover all conditions of the catchment and it has to adjust itself (by adjusting model parameters) to represent different conditions. As a consequence, model parameters are usually temporally different for varied rainfall-runoff events. The dynamics of model parameters identified from event-based model calibration using measured rainfall and runoff data thus possibly represent temporal catchment characteristics and conditions. For instance, in our urban rainfall-runoff conceptual model, the initial loss roughly indicates the antecedent weather condition of an event; the proportional loss is probably an indicator of imperviousness; the time shift and reservoir constant are related to the time of the catchment responding to rainfall. These model parameters can further be used to study the evolution of long-term catchment properties.

The model is calibrated using the DREAM algorithm (Vrugt et al., 2008), which searches for optimal parameters based on the Monte Carlo Markov Chain method. The effectiveness of DREAM in calibrating hydrological models has been demonstrated by many studies in the literature (e.g., Schoups et al., 2010).

\subsection{Time of concentration estimated from conceptual rainfall-runoff model parameters}

The time of concentration, which is usually defined as the time of water flowing from the point with the longest temporal flow path within a catchment to the catchment outlet, also measures the response time of a catchment to a rain event. The time of concentration is an important concept in hydrology because many practical designs and operation strategies rely on the prediction of the catchment response time. The most common method to estimate the time of concentration is via the identification of the flow path and the time of concentration is the travel time of flows through the flow path. In this study, the time of concentration is computed as the length of a unit hydrograph, which is the response of a watershed (in terms of 
runoff volume and timing) to the input of a unit of rainfall. Once the urban hydrological model is calibrated for a specific event, its unit hydrograph can be determined as a function of two calibrated model parameters (i.e., the time shift and reservoir constant). More specifically, a unit depth of net rainfall is input into the urban rainfall-runoff model (Eqs. (2) and (3)) with the two calibrated model parameters, and the model output is its corresponding unit hydrograph. Because a unit hydrograph from the linear reservoir model has a very long recession limb, the time of concentration is estimated as the duration when $95 \%$ water volume reaches the watershed outlet (a higher percentage of volume generally does not change the relative magnitudes of the time of concentration from different hydrographs).

\subsection{Uncertainty in trend analysis due to noisy events}

Due to various reasons (e.g., measurement uncertainty, data errors and uncertainty in model calibration), there might be erroneous values (from a noisy event) in data series. To study the influence of the erroneous values on the trend detection results, uncertainty in trend detection results due to erroneous values in data series is examined. One synthetic noisy value is introduced into a data series at different positions. A noisy value is assumed to be extremely big, small or median. An extremely big (small) value is even bigger (smaller) than the maximum (minimum) value in the data series. The sensitivity of the trend detection results to the magnitude and position of noisy values is then investigated by comparing the results of the data series without and with an erroneous value.

\section{Results and discussion}

\subsection{Rainfall-Runoff event characteristics}

A total number of 692 significant events in Chassieu and 584 significant events in La Lechere have been identified with complete one-minute or two-minute rainfall time series. A total number of 584 and 442 runoff events are identified with complete runoff data with mean flow 
over $5 \mathrm{~L} / \mathrm{s}$ in Chassieu and La Lechere, respectively. The conceptual urban hydrological model described above is calibrated to fit the rainfall and runoff data for each specific event (see Section 4.3 for more details on the model calibration results). Most events (477 events in Chassieu and 398 events in La Lechere) can be satisfactorily described by the conceptual urban rainfall-runoff model with a Nash-Sutcliffe (NS) model efficiency coefficient over 0.7. However, for a small number of events, the conceptual urban rainfall-runoff model produces outputs with significant discrepancies from the measured data. This is likely due to errors either in rainfall or runoff measurements (e.g., catchment areal rainfall not captured by point measurement, Leonhardt et al., 2014) or the simple assumption of a constant baseflow. Only events that can be satisfactorily described by the conceptual urban rainfall-runoff model are considered for the following trend analysis. Fig. 1 shows the rainfall depth and duration of all rainfall events and selected events that can be satisfactorily described by the conceptual urban rainfall-runoff model.

Table 1 summarizes some statistical characteristics of the rainfall and runoff variables of the selected events in the two catchments. The runoff-based variables are considered after subtracting the baseflow, because this study is only concerned with the fast response of the urban areas to rainfall. Big rainfall events were observed with a maximum rainfall depth of 134.6 $\mathrm{mm}$ in Chassieu and $91.4 \mathrm{~mm}$ in La Lechere. The rainfall and runoff variables were generally distributed over wide ranges, with relative standard deviations typically over 1 , indicating positively skewed distributions of the variables, which are consistent with previous findings (Brezonik and Stadelmann, 2002).

\subsection{Trend analysis of simple variables without modelling}

Variables of the selected events based on simple data analysis, i.e., baseflow, runoff coefficient and lag time, are shown in Fig. 2 for the two catchments. Their statistical characteristics are also summarized in Table 1. 
In Chassieu, the baseflow values are mostly under $25 \mathrm{~L} / \mathrm{s}$ with a median value of $2.0 \mathrm{~L} / \mathrm{s}$. Only a few values in the latter years are over $25 \mathrm{~L} / \mathrm{s}$. Values of the runoff coefficient are between 0.03 and 0.81 , with a median value of 0.30 . The wide range of the runoff coefficient can be explained by influential factors such as initial loss and dry weather flows, which are eventspecific. The lag time also covers a large range, mostly between 20 and 200 minutes with a median of 77 minutes and with two negative values. The negative lag time of one event is likely due to errors in rainfall and runoff measurements and the assumption of a constant baseflow. The lag time varies depending on the profiles of the hyetograph and hydrograph, due to the non-linear relationship between rainfall and runoff and possibly varied temporal hydrological regimes.

In La Lechere, the median baseflow is $7.2 \mathrm{~L} / \mathrm{s}$ and most values are in the interval of $[0,100]$. One event with an extreme baseflow (over $300 \mathrm{~L} / \mathrm{s}$ ) occurred at the end of 2008, which can be explained by a rainfall event of $73.4 \mathrm{~mm}$ ending only 15 hours before it, discharging high natural flow from rural areas. The runoff coefficient is distributed across a range of $[0.01,0.3]$, with a median value of 0.04 . The generally low runoff coefficient (in comparison with that of Chassieu) is found because only CSOs contribute to the considered runoff in La Lechere. The median lag time is 110 minutes, with the range in $[-50,405]$ minutes.

Table 2 lists trend detection results for different rainfall and runoff variables. The original or modified Mann-Kendall test is applied according to the significance of the autocorrelation test. For both catchments, no trend is found for most rainfall-based variables, including depth, duration and mean intensity. A relatively low $P$-value of $3.2 \%$ is obtained for the rainfall duration in La Lechere, which is significant at the 5\% significance level, but is still above the less strict $1 \%$ significance level. In addition, the trend test is performed on many other rainfall variables in addition to those listed in Table 2 (e.g., rainfall depth and intensity in a specific 
duration). The results indicate no trend in any rainfall-based variables. There is likely no trend in the rainfall variables (the driver of the hydrological process) for the study period.

For the urban runoff-based variables, data series of the runoff volume and mean runoff flow are investigated. According to the original or modified Mann-Kendall test, all variables present an increasing trend with $P$-values on the order of $1 \%$ or lower. The mean urban runoff flow rate increases by $3.1 \mathrm{~L} / \mathrm{s}$ in Chassieu and $0.7 \mathrm{~L} / \mathrm{s}$ in La Lechere on average per year.

As a result of the relatively stable rainfall and increasing runoff, an increasing trend is detected in the runoff coefficient in both catchments with very low $P$-values (on the order of $10^{-11}$ in Chassieu and $10^{-3}$ in La Lechere). The overall increasing rates of the runoff coefficient are evaluated as 0.012 and 0.002 per year in Chassieu and La Lechere, respectively. The increasing runoff coefficient is likely due to growing imperviousness caused by urbanization in both catchments. In Chassieu, a comparison of aerial views at the beginning and end of the study period shows more buildings being constructed, which led to increasing imperviousness during the study period (Sun et al., 2015). However, it is worth noting that urbanization can only be regarded indicative to runoff coefficient changes, because urbanization does not always lead to higher runoff volumes, particularly with the implementation of low urban development (LID) techniques such as porous pavement, infiltration trenches and green roofs. In contrast, the lag time seems not to present a trend, indicating no significant change in the travel time of flows in the catchments.

An increasing trend in the baseflow is confirmed in Chassieu with a $P$-value of $2.3 \%$, indicating more industrial wastewater draining into the system, whereas no trend is detected in the baseflow in La Lechere, implying a relatively stable rural flow in this area.

\subsection{Conceptual urban rainfall-runoff model based analysis}


An event-based calibration is implemented for all of the available rainfall-runoff events in the two catchments based on measured rainfall and runoff data. The optimal model parameters for each event are identified using the DREAM algorithm based on $10^{4}$ model evaluations. The search ranges of the model parameters, which are determined based on catchment properties, are given in Table 3. Only events that are satisfactorily described by the conceptual rainfallrunoff model with an NS value over 0.7 are considered. Table 3 also lists the summary statistics of the optimal model parameters. Fig. 3 shows the optimal model parameters. The parameter of initial loss is broadly distributed in the search range of $[0-2 \mathrm{~mm}]$ or $[0-3 \mathrm{~mm}]$ in the two catchments, with several events reaching the limits. However, the limits are not extended to reflect the physical reality in the catchments. The proportional loss is also eventdependent and distributed in a wide range with a median of 0.65 in Chassieu and 0.88 in La Lechere. This parameter can be roughly linked to the runoff coefficient, with the absolute values of the correlation coefficients of 0.73 in Chassiu and 0.83 in La Lechere. The reservoir constant and time shift reveal the response time of the catchments to rainfall events. These two parameters also show great variability.

The temporal variability of the model parameters implies that the lumped conceptual urban rainfall-runoff model is too simple to cover all conditions encountered by all of the events in the urban catchments, which is consistent with previous findings (Maneta et al., 2007). The calibrated parameters reveal the temporal hydrological regime/conditions during one specific event. However, the variability of optimal model parameters may also result from other reasons, leading to bias in some model parameter estimates in the lumped conceptual urban rainfall-runoff model. For instance, errors in areal rainfall (represented by point measurements) and runoff measurements lead to biased calibration results, as in calibration, the model parameters are adjusted to make the lumped model outputs match the measurements. Additionally, the model parameters are correlated (e.g., Sun and Bertrand-Krajewski, 2013). 
Author-produced version of the article published in Hydrological Processes, Volume 31, Issue 6, 15 March 2017, Pages 1349-1359 The original publication is available at http://onlinelibrary.wiley.com/doi/10.1002/hyp.11109/abstract

Manuscript accepted for publication in Hydrological Processes, December 2016, doi: 10.1002/hyp.11109

358

359

360

361

362

363

364

365

366

367

368

369

370

371

372

373

374

375

The initial loss and proportional loss are negatively correlated; the reservoir constant and the time shift are also negatively correlated. Simultaneously adjusting correlated parameters gives equivalent model performances.

The time of concentration for each event is evaluated from the calibrated reservoir constant and time shift (Fig. 4). The median time of concentration in Chassieu is 92 minutes and most values are in the range of [10-400]. The time of concentration in La Lechere covers a range of $[24,724]$ minutes and the median is 132 minutes.

Fig. 5 shows the scatter points of the lag time directly derived from the data and the time of concentration estimated from calibrated urban rainfall-runoff model parameters. These two quantities both indicating the response time of the urban catchments to rainfall events are highly correlated. However, the relation between these two variables also shows some randomness, resulting from the non-linear relation between rainfall and runoff and the different methods with which the two parameters are calculated.

Assuming that other factors listed above (e.g., errors in rainfall and runoff data, uncertainty in calibration and parameter correlation) leading to temporal variation of model parameters are random without a trend, trend analysis of model parameters can still provide useful information on hydrological regime evolution in the two catchments. Table 4 lists the trend detection results of optimal model parameters along with the time of concentration. The initial loss does not present a trend in both catchments, indicating stable initial conditions of rainfall events, which are linked to antecedent dry periods and precedent events. A decreasing trend is found in the constant loss in both catchments with low $P$-values, which is consistent with the detected increasing trend in the runoff coefficient in the above analysis due to urban development in the catchments. The constant loss is evaluated with a decreasing rate of approximately 0.014 per year in Chassieu and 0.005 in La Lechere. These figures are close to 
the values of the increasing rates in the runoff coefficient estimated using the simple data analysis method (see Table 2).

The reservoir constant and lag time in Chassieu seem to not contain a trend according to the Mann-Kendall method, suggesting that the routing function governing runoff generation does not have a significant change in Chassieu. In contrast, the reservoir constant possibly presents a decreasing tendency in La Lechere with a $P$-value under 5\%. Consequently, the time of concentration evaluated based on this parameter in La Lechere is also detected with a declining trend of approximately 3.5 minutes per year. This is consistent with the common sense notion that urbanization leads to a shorter time of concentration because an artificial drainage system often transports stormwater much faster than a natural water course. In the study period of ten years, a decrease of 35 minutes in the concentration time is expected, which is non-negligible in comparison with the median time of concentration of 132 minutes. However, the trends in both variables are rejected with the stricter $1 \%$ significance level. Further data are required in order to confirm the trend in these variables.

\subsection{Sensitivity of noisy events to trend detection results}

Due to the various reasons presented above (e.g., the lumped and simplified model representing the complex rainfall-runoff process, errors in rainfall and runoff measurements and the correlation between model parameters in calibration), parameters characterizing local hydrology obtained from data analysis and model calibration for some events may be erroneous. For instance, the negative lag time and the reservoir constant of three events in La Lechere close to 240 minutes (which is the search limit) are likely to be erroneous. This section investigates the influence of the presence of noisy events (with erroneous values) in the data series on the trend detection results using the Mann-Kendall test. 
Four data series of optimal model parameters are used to study the sensitivity of trend detection results to noisy values. The original data series are considered as the comparison benchmarks, assuming that they do not contain any erroneous data. Fig. 6 shows the $P$-values of different cases with one noisy value together with the $P$-value of the original data series. It is clear that the influence of a noisy event depends both on the magnitude and the position of the noisy event.

In Fig. 6 (a), the data series of the initial loss in Chassieu, which does not present a trend is studied. The original Mann-Kendall method is used because the autocorrelation effect in the data series is insignificant. An extreme noisy value introduced at the two sides of the data series leads to the most significant change in the $P$-value. The influence of a noisy value is negligible when it is in a middle position in the data series. A noisy median value does not significantly affect the $P$-value at any position in the data series. The $P$-value changes gradually as a noisy event moves in the data series.

In Fig. 6(b), the data series of the constant loss in Chassieu, which presents a decreasing trend as indicated by the original Mann-Kendall method, is studied. An extremely high noisy value located at the beginning of the data series leads to a lower $P$-Value, as expected. An extreme noisy value in the middle positions of the data series and a noisy median value at any position do not have significant impacts on the $P$-value.

In Fig. 6 (c) and (d), data series of the constant loss and time shift in La Lechere with significant autocorrelation are studied using the modified Mann-Kendall method. Different from those in Fig. 6 (a) and (b), the $P$-values do not change monotonously as the position of a noisy value changes gradually in a data series, due to the influence of the autocorrelation coefficients incorporated in the modified Mann-Kendall test. The relation between the $P$ value and the position of an erroneous value is rather random. The most significant change in 
a $P$-value due to an extreme noisy value does not necessarily occur when it is located at the two sides of the data series. In both cases, the introduction of one erroneous value does not change the trend detection results.

Furthermore, the impact of the number of noisy values on the trend detection results using the original Mann-Kendall method is also studied. The trend detection results from the original Mann-Kendall method are most sensitive to extreme erroneous values at the two sides of the data series. Therefore, the impact of the number of noisy values is studied here by examining cases with extreme noisy values introduced in the beginning of data series. Fig. 7 shows the results. In Fig. 7(a), for the data series of the initial loss (containing 477 events) in Chassieu, which does not present a trend, a trend will only be detected with more than 9 extremely small noisy events or 21 extremely large events introduced in the beginning of the data series. In Fig. 7(b), for the constant loss data series in Chassieu presenting a significantly decreasing trend with a $P$-value of $2.7 \times 10^{-9} \%$, the Mann-Kendall test only gives a different indication of trend absence when over 32 extremely small noisy values are introduced.

Based on the above analysis, a different trend result generally requires a number of extreme erroneous values at one side of a data series. The Mann-Kendall method, which is a function of the ranks of the observations rather than their actual values, is not sensitive to a few noisy values. Therefore, in this study, the trend detection results using the original Mann-Kendall method are probably reliable regardless of a few possible noisy values in the data series. However, the sensitivity of the trend detection results from the modified Mann-Kendall method seems to be more complicated due to the altered autocorrelation coefficients.

\section{Conclusions}

It is important to assess any hydrological trend (if one exists) in urban catchments because the design and operation of urban stormwater projects aiming to reduce the adverse impact of 
stormwater should take into account possible changes in urban hydrology patterns. This paper addresses hydrological trend analysis in urban catchments. Using rainfall and runoff data and a conceptual rainfall-runoff model, lumped parameters that aggregate distributed spatial information in the urban/peri-urban catchments are analysed to reveal the global evolution of the hydrological responses (noting that distributed processes, factors and properties on smaller scales in local hydrology are beyond the discussion). The evolution of aggregate hydrologic relevant parameters is useful in indicating changes in local hydrology and needs to be considered in urban stormwater management. The original and modified Mann-Kendall methods are applied for trend detection in data series in two catchments in France, i.e., Chassieu and La Lechere, and there seems to be no difficulty of applying the methodology to other urban catchments. Based on the application results for approximately one decade of data, the following conclusions can be drawn:

1. A trend is absent in the driving force (precipitation) of the rainfall-runoff processes in both catchments in the suburbs of Lyon for the study period.

2. An increasing trend is found in the urban runoff variables. On average, the mean runoff flow rate increases by $3.1 \mathrm{~L} / \mathrm{s}$ in Chassieu and $0.7 \mathrm{~L} / \mathrm{s}$ in La Lechere per year.

3. As a result of the relatively stable rainfall and increasing urban runoff volumes, the runoff coefficient presents an increasing trend in both catchments, probably due to growing imperviousness caused by urbanization, even in Chassieu, where the catchment is already very densely urbanized, rather than climate change factors. However, it is worth noting that nowadays urbanization does not automatically lead to more imperviousness and increasing catchment outflow. The influence of urbanization development on the local hydrological processes is much more complicated than simple imperviousness evolution because it is highly dependent on the detailed changes and processes. For instance, in the LID context, 
when urban areas expand, water on the impervious surface can be connected to vegetated areas or infiltration devices; some rain can be retained via green roofs. In addition, the efficiency of an LID device may decline over time (e.g., when an infiltration system is clogged), leading to a part of stormwater back to catchment outflow. Therefore, the evolution of stormwater quantities is difficult to be precisely inferred only from urbanization information. The methodology developed in this study provides the most direct evidence of the elevated runoff coefficient in urban/peri-urban catchments.

4. Optimal parameters of a conceptual urban rainfall -runoff model obtained from calibration using an event-based approach are used to represent the temporal hydrological regime.

Though temporal variation of optimal model parameters is also affected by other factors such as errors in rainfall and runoff measurements, uncertainty in calibration and parameter correlation, the variance due to these factors is assumed to be random. The trend analysis results of these model parameters therefore reveal local hydrology evolution. No trend is present in the initial loss. A decreasing trend is found in the constant proportional loss in both catchments, which is consistent with the increasing runoff coefficient. The time of concentration in Chassieu does not exhibit a trend, whereas it seems to decrease by 3.5 minutes per year in La Lechere. The trend in the time of concentration in La Lechere needs to be confirmed with further data.

5. The sensitivity analysis indicates that the original Mann-Kendall method is not sensitive to a few noisy values in the data series. Therefore, the trend detection results from the original Mann-Kendall method are reliable, regardless of a few possible erroneous data. However, the relation between trend detection results and noisy values using the modified Mann-Kendall method is rather complicated and difficult to quantify. 
Author-produced version of the article published in Hydrological Processes, Volume 31, Issue 6, 15 March 2017, Pages 1349-1359 The original publication is available at http://onlinelibrary.wiley.com/doi/10.1002/hyp.11109/abstract

Manuscript accepted for publication in Hydrological Processes, December 2016, doi: 10.1002/hyp.11109

\section{Acknowledgements}

502 The authors wish to acknowledge the Rhone-Mediterranean and Corsica Water Agency for

503 the financial support of the CHRONOTHU project, under which the presented study was

504 conducted. The authors also acknowledge the Greater Lyon for providing technical and

505 financial support to OTHU (www.othu.org) for the monitoring database.

506 


\section{References}

Astaraie-Imani, M., Kapelan, Z., Fu, G., Butler, D. (2012). Assessing the combined effects of urbanization and climate change on the river water quality in an integrated urban wastewater system in the UK. Journal of Environmental Management. 112: 1-9.

Aziz, O.I.A., Burn, D.H. (2006). Trends and variability in the hydrological regime of the Mackenzie revier basin. Journal of Hydrology. 319: 282-294.

Awadallah, A.G., Fahmy, H., Karaman, H.G. (2011). Trend detection in water quality data using time series seasonal adjustment and statistical tests. Irrigation and Drainage. 60(2): 253262.

Braud, I., Breil, P., Thollet, F., Lagouy, M., Branger, F., Jacqueminet, C., Kermadi, S., Michel, K. (2013). Evidence of the impact of urbanization on the hydrological regime of a mediumsized periurban catchment in France, Journal of Hydrology, 485: 5-23

Brezonik, P.L., Stadelmann, T.H. (2002). Analysis and predictive models of stormwater runoff volumes, loads and pollutant concentrations from watersheds in the Twin Cities metropolitan area, Minnesota, USA. Water Research. 36: 1743-1757.

Burn, D.H., Elnur, M.A.H. (2002). Detection of hydrologic trends and variability. Journal of Hydrology. 255: 107-122.

Chiew, FHS., Peel, MC., Western, AW. (2002). Application and testing of the simple rainfallrunoff model SIMHYD. In book: Mathematical models of small watershed hydrology and applications. pp 335-367.

Douglas, E.M., Vogel, R.M., Kroll, C.N. (2000). Trends in floods and low flows in the United States; impact of spatial correlation. Journal of Hydrology. 240: 90-105.

Gocic, M., Trajkovic, S. (2013). Analysis of changes in meteorological variables using MannKendall and Sen's slope estimator statistical tests in Serbia. Global and Planetary Change. 100: 172-182.

Hamed, K.H., Rao, A.R. (1998). A modified Mann-Kendall trend test for autocorrelated data. Journal of Hydrology. 204: 182-196.

Hess, A., Iyer, H., Malm, W. (2001). Linear trend analysis: a comparison of methods. Atmospheric Environment. 35: 5211-5222.

Hirsch, R.M., Slack, J.R. \& Smith, R.A. (1982). Techniques of trend analysis for monthly water quality analysis. Water Resource Research. 18(1): 107-121

Hirsch, R.M., Slack, J.R. (1984). Non-parametric trend test for seasonal data with serial dependence. Water Resources Research. 20: 727-732. 
Métadier, M., Bertrand-Krajewski J.-L. (2012). Pollutographs, concentrations, loads and intraevent mass distributions of pollutants in urban wet weather discharges calculated from long term on turbidity measurements. Water Research. 46(20): 6836-6856.

Jankowsky, S., Branger, F., Braud, I., Rodriguez, F., Debionne, S., Viallet, P. (2014). Assessing anthropogenic influence on the hydrology of small peri-urban catchments: development of the object-oriented PUMMA model by integrating urban and rural hydrological models, Journal of Hydrology. 517: 1056-1071

Kendall, M.G. (1955). Rank Correlation Methods. Griffin, London.

Leonhardt, G., Sun, S., Rauch, W., Bertrand-Krajewski J.-L. (2014). Comparison of two model based approaches for areal rainfall estimation in urban hydrology. Journal of Hydrology. 511: 880-890.

Maneta, M.P., Pasternack, G.B., Wallender, W.W., Jetten, V., Schnabel, S. (2007). Temporal instability of parameters in an event-based distributed hydrologic model applied to a small semiarid catchment Journal of Hydrology. 341: 207-221.

Mann, H.B., (1945). Nonparametric tests against trend, Econometrica, 13, 245-259.

Omar, I, Aziz, A., Burn, DH. (2006). Trends and variability in the hydrological regime of the Mackenzie River Basin. Journal of Hydrology. 319: 282-294.

Partal, T., Kahya, E. (2006). Trend analysis in Turkish precipitation data. Hydrological Processes. 20: 2011-2026.

Post, D., Jakeman, A.J. (1999). Predicting the daily streamflow of ungauged catchments in S.E. Australia by regionalizing the parameters of a lumped conceptual rainfall-runoff model. Ecological Modelling. 23(2-3): 91-104.

Schoups, G., Vrugt, J.A., Fenicia, F., and Giesen, N.C.van de. (2010). Corruption of accuracy and efficiency of Markov chain Monte Carlo simulation by inaccurate numerical implementation of conceptual hydrologic models. Water Resources Research. 46, W10530. doi:10.1029/2009WR008648.

Sun, S., Bertrand-Krajewski, J.-L. (2013). Separately accounting for uncertainties in rainfall and runoff: Calibration of event based conceptual hydrological models in small urban catchments using Bayesian method. Water Resources Research, 49: 1-14.

Sun, S., Barraud, S., Castebrunet, H., Aubin, J.-B., Marmonier, P. (2015). Long-term stormwater quantity and quality analysis using continuous measurements in a French Urban Catchment. Water Research. 85:432-442.

Sen, P. K. (1968). Estimates of the regression coefficient based on Kendall's Tau, Journal of the American Statistical Association. 63: 1379-1389.

Vrugt, J.A., Ter Braak C.J.K., Clark M.P. Hyman J.M., and Robinson B.A. (2008). Treatment of input uncertainty in hydrologic modeling: doing hydrology backward with Markov chain 
576 Monte Carlo simuation. Water Resources Research, 44, W00B09,

577 doi:10.1029/2007WR006720

578 Xu, Z.X., Takeuchi, K., Ishidaira, H. (2003). Monotonic trend and step changes in Japanese

579 Precipitation. Journal of Hydrology. 279 (1-4): 144-150.

580 Yue, S., Pilon, P., Phinney, B., Cavadias, G. (2002). The influence of autocorrelation on the 581 ability to detect trend in hydrological series. Hydrological Processes. 16: 1807-1829.

582 Zhang, X., Harvey, K.D., Kogg, W.D., Yuzyk, T.R. (2001). Trends in Canadian streamflow. 583 Water Resources Research. 37(4): 987-998. 
Manuscript accepted for publication in Hydrological Processes, December 2016, doi: 10.1002/hyp.11109

585

586

587

588

589

590

591

592

593

594

595

596

597

598

599

\section{Figure captions}

Fig 1. All rainfall events and events that can be satisfactorily described by rainfall-runoff model: (a) Chassieu; (b) La Lechere

Fig 2. Simple variables in chronological order: (1) Chassieu; (2) La Lechere

Fig 3. Optimal model parameters of conceptual urban rainfall-runoff models using eventbased calibration: (1) Chassieu; (2) La Lechere

Fig 4. Time of concentration from calibrated model parameters: (a) Chassieu; (b) La Lechere Fig 5. Scatter plots of lag time and time of concentration: (a) Chassieu; (b) La Lechere Fig 6. Sensitivity of P-values to one noisy value: (a) the initial loss in Chassieu; (b) the constant loss in Chassieu; (c) the constant loss in La Lechere; (d) the time shift in La Lechere Fig 7. Sensitivity of $P$-values to a number of extreme events introduced in the beginning of data series using the original Mann-Kendall method: (a) the initial loss in Chassieu; (b) the constant loss in Chassieu. 
Author-produced version of the article published in Hydrological Processes, Volume 31, Issue 6, 15 March 2017, Pages 1349-1359 The original publication is available at http://onlinelibrary.wiley.com/doi/10.1002/hyp.11109/abstract

Manuscript accepted for publication in Hydrological Processes, December 2016, doi: 10.1002/hyp.11109

600 Table captions

601 Table 1. Statistical characteristics of event-based variables in Chassieu and La Lechere

602 Table 2. Trend detection results on simple variables without modeling

603 Table 3. Parameters of conceptual rainfall-runoff model in the two catchments

604 Table 4. Trend detection results for the parameters in the conceptual urban rainfall-runoff

605 model

606 
Manuscript accepted for publication in Hydrological Processes, December 2016, doi: 10.1002/hyp.11109

Table 1. Statistical characteristics of event-based variables in Chassieu and La Lechere

\begin{tabular}{|c|c|c|c|c|}
\hline Catchment & Variables & Characteristics & $\begin{array}{l}\text { Median [min- } \\
\max ]\end{array}$ & $\begin{array}{l}\text { Mean (standard } \\
\text { deviation) }\end{array}$ \\
\hline \multirow{8}{*}{$\begin{array}{l}\text { Chassieu } \\
\text { (477 events) }\end{array}$} & \multirow{3}{*}{ Rainfall } & Depth (mm) & $4.8[1.2-134.6]$ & $9.0(12.5)$ \\
\hline & & Duration $(\mathrm{h})$ & $4.7[0.6-42.6]$ & $6.8(6.3)$ \\
\hline & & $\begin{array}{l}\text { Mean intensity } \\
(\mathrm{mm} / \mathrm{h})\end{array}$ & $1.00[0.21-23.1]$ & $1.70(2.12)$ \\
\hline & \multirow{2}{*}{$\begin{array}{l}\text { Runoff } \\
\text { deducted with } \\
\text { baseflow }\end{array}$} & $\begin{array}{l}\text { Total volume } \\
\left(\times 10^{3} \mathrm{~m}^{3}\right)\end{array}$ & $2.00[0.16-60.7]$ & $4.29(6.68)$ \\
\hline & & $\begin{array}{l}\text { Average rate } \\
(\mathrm{L} / \mathrm{s})\end{array}$ & $58.2[0.90-805.7]$ & $98.7(112.0)$ \\
\hline & Baseflow & $(\mathrm{L} / \mathrm{s})$ & $2.0[0.0-46.8]$ & $4.5(5.4)$ \\
\hline & \multirow{2}{*}{$\begin{array}{l}\text { Rainfall-runoff } \\
\text { process }\end{array}$} & $\begin{array}{l}\text { Runoff } \\
\text { coefficient (-) }\end{array}$ & $0.30[0.03-0.81]$ & $0.31(0.10)$ \\
\hline & & Lag time (min) & $77.1[-23.0-207.4]$ & $81.1(33.5)$ \\
\hline \multirow{8}{*}{$\begin{array}{l}\text { La Lechere } \\
\text { (398 events) }\end{array}$} & \multirow{3}{*}{ Rainfall } & Depth (mm) & $7.4[2.0-91.4]$ & $10.6(10.1)$ \\
\hline & & Duration (h) & $5.9[0.5-33.8]$ & $7.7(6.4)$ \\
\hline & & $\begin{array}{l}\text { Mean intensity } \\
(\mathrm{mm} / \mathrm{h})\end{array}$ & $1.4[0.3-16.3]$ & $2.0(2.0)$ \\
\hline & \multirow{2}{*}{$\begin{array}{l}\text { runoff } \\
\text { deducted with } \\
\text { baseflow }\end{array}$} & $\begin{array}{l}\text { Total volume } \\
\left(\times 10^{3} \mathrm{~m}^{3}\right)\end{array}$ & $0.93[0.10-28.0]$ & $2.07(3.34)$ \\
\hline & & $\begin{array}{l}\text { Average rate } \\
(\mathrm{L} / \mathrm{s})\end{array}$ & $24.3[5.0-410.6]$ & $44.7(55.3)$ \\
\hline & Baseflow & $(\mathrm{L} / \mathrm{s})$ & $7.2[0-317.6]$ & $15.8(25.6)$ \\
\hline & \multirow{2}{*}{$\begin{array}{l}\text { Rainfall-runoff } \\
\text { process }\end{array}$} & $\begin{array}{l}\text { Runoff } \\
\text { coefficient (-) }\end{array}$ & $0.04[0.01-0.30]$ & $0.05(0.04)$ \\
\hline & & Lag time (min) & $110[-50-405]$ & $121(57)$ \\
\hline
\end{tabular}


Table 2. Trend detection results on simple variables without modeling

\begin{tabular}{|c|c|c|c|c|c|}
\hline & Variable & Parameter & $\begin{array}{l}\text { Mann- } \\
\text { Kendall } \\
\text { test }\end{array}$ & $\begin{array}{l}P \text {-value } \\
(\%)\end{array}$ & $\begin{array}{l}\text { Slope } \\
(- \\
\text { /year })\end{array}$ \\
\hline \multirow{8}{*}{$\begin{array}{l}\text { Chassieu } \\
\text { (477 events) }\end{array}$} & \multirow[t]{3}{*}{ Rainfall } & Depth (mm) & Original & 10.2 & - \\
\hline & & Duration (h) & Original & 58.2 & - \\
\hline & & Mean intensity $(\mathrm{mm} / \mathrm{h})$ & Modified & 12.5 & - \\
\hline & \multirow[t]{2}{*}{$\begin{array}{l}\text { Runoff without } \\
\text { baseflow }\end{array}$} & $\begin{array}{l}\text { Total runoff volume } \\
\left(\mathrm{m}^{3}\right)\end{array}$ & Original & $0.1^{* * *}$ & 98.7 \\
\hline & & $\begin{array}{l}\text { Mean runoff flow rate } \\
(\mathrm{L} / \mathrm{s})\end{array}$ & Original & $1.2 \times 10^{-2 * *}$ & 3.1 \\
\hline & \multirow{2}{*}{$\begin{array}{l}\text { Rainfall-runoff } \\
\text { processes }\end{array}$} & Runoff coefficient (-) & Original & $1.4 \times 10^{-9 * * *}$ & 0.012 \\
\hline & & Lag time (min) & Modified & 43.6 & - \\
\hline & Other & Baseflow (L/s) & Modified & $2.3^{*}$ & 0.32 \\
\hline \multirow{8}{*}{$\begin{array}{l}\text { La Lechere } \\
\text { (398 events) }\end{array}$} & \multirow[t]{3}{*}{ Rainfall } & Depth (mm) & Original & 34.6 & - \\
\hline & & Duration $(\mathrm{h})$ & Original & $3.2^{*}$ & 0.18 \\
\hline & & Mean intensity $(\mathrm{mm} / \mathrm{h})$ & Original & 6.0 & - \\
\hline & \multirow[t]{2}{*}{ Runoff } & $\begin{array}{l}\text { Total runoff volume } \\
\left(\mathrm{m}^{3}\right)\end{array}$ & Original & $0.9^{* * *}$ & 35.8 \\
\hline & & $\begin{array}{l}\text { Mean runoff flow rate } \\
(\mathrm{L} / \mathrm{s})\end{array}$ & Original & $3.7^{*}$ & 0.7 \\
\hline & \multirow{2}{*}{$\begin{array}{l}\text { Rainfall-runoff } \\
\text { processes }\end{array}$} & Runoff coefficient (-) & Modified & $0.2^{* * *}$ & 0.002 \\
\hline & & Lag time $(\min )$ & Modified & 68.5 & - \\
\hline & Other & Baseflow (L/s) & Modified & 55.6 & - \\
\hline
\end{tabular}

\begin{tabular}{|c|c|c|c|c|c|c|}
\hline \multirow[b]{2}{*}{ parameter } & \multicolumn{4}{|c|}{ Chassieu } & \multicolumn{2}{|c|}{ La Lechere } \\
\hline & $\begin{array}{l}\text { Search } \\
\text { range }\end{array}$ & $\begin{array}{l}\text { Median } \\
{[\text { min- }} \\
\max ]\end{array}$ & $\begin{array}{c}\text { Mean } \\
\text { (standard } \\
\text { deviation) }\end{array}$ & $\begin{array}{l}\text { Search } \\
\text { range }\end{array}$ & $\begin{array}{c}\text { Median } \\
{[\min -\max ]}\end{array}$ & $\begin{array}{c}\text { Mean } \\
\text { (standard } \\
\text { deviation) }\end{array}$ \\
\hline $\begin{array}{l}\text { Initial loss } \\
(\mathrm{mm})\end{array}$ & {$[0,2]$} & $\begin{array}{l}0.67[0.0- \\
2.0]\end{array}$ & $0.79(0.59)$ & {$[0,3]$} & $1.6[0.0-3.0]$ & $1.6(1.1)$ \\
\hline $\begin{array}{l}\text { Constant } \\
\text { loss (-) }\end{array}$ & {$[0,1]$} & $\begin{array}{l}0.65[0.0- \\
0.98]\end{array}$ & $0.64(0.14)$ & {$[0,1]$} & $\begin{array}{l}0.88 \\
{[0.25,0.97]}\end{array}$ & $0.86(0.09)$ \\
\hline $\begin{array}{l}\text { Reservoir } \\
\text { constant } \\
(\mathrm{min}) \\
\end{array}$ & {$[1,120]$} & $\begin{array}{l}15.5[1.0- \\
90.2]\end{array}$ & $19.0(12.0)$ & {$[1,240]$} & $\begin{array}{l}26.6[2.4- \\
240]\end{array}$ & $36.3(34.9)$ \\
\hline $\begin{array}{l}\text { Time shift } \\
(\min )\end{array}$ & {$[1,60]$} & $\begin{array}{l}14.0[1.2- \\
60.0]\end{array}$ & $16.1(11.9)$ & {$[1,120]$} & 2 [0-66] & $4.5(7.0)$ \\
\hline
\end{tabular}
at $1 \%$ level.

Table 3. Parameters of conceptual rainfall-runoff model in the two catchments 
Author-produced version of the article published in Hydrological Processes, Volume 31, Issue 6, 15 March 2017, Pages 1349-1359 The original publication is available at http://onlinelibrary.wiley.com/doi/10.1002/hyp.11109/abstract

Manuscript accepted for publication in Hydrological Processes, December 2016, doi: 10.1002/hyp.11109

617

618

\begin{tabular}{|c|c|c|c|c|c|}
\hline & & Parameter & $\begin{array}{l}\text { Mann- } \\
\text { Kendall test }\end{array}$ & $\begin{array}{l}\text { P-value } \\
(\%)\end{array}$ & $\begin{array}{l}\text { Slope (- } \\
\text { /year) }\end{array}$ \\
\hline \multirow{5}{*}{$\begin{array}{l}\text { Chassieu (477 } \\
\text { events) }\end{array}$} & \multirow{4}{*}{$\begin{array}{l}\text { Model } \\
\text { parameters }\end{array}$} & Initial loss & Original & 43.2 & - \\
\hline & & Constant loss & Original & $2.7 \times 10^{-}$ & -0.014 \\
\hline & & Reservoir constant & Modified & 39.9 & - \\
\hline & & Time shift & Modified & 88.5 & - \\
\hline & $\begin{array}{l}\text { Other } \\
\text { parameters }\end{array}$ & $\begin{array}{l}\text { Time of } \\
\text { concentration (min) }\end{array}$ & Modified & 99.1 & - \\
\hline \multirow{5}{*}{$\begin{array}{l}\text { La Lechere } \\
\text { (398 events) }\end{array}$} & \multirow{4}{*}{$\begin{array}{l}\text { Model } \\
\text { parameters }\end{array}$} & Initial loss & Modified & 19.2 & - \\
\hline & & Constant loss & Modified & $0.01^{* *}$ & -0.005 \\
\hline & & Reservoir constant & Modified & $0.3^{* *}$ & -0.8 \\
\hline & & Time shift & Original & 97.2 & - \\
\hline & $\begin{array}{l}\text { Other } \\
\text { parameters }\end{array}$ & $\begin{array}{l}\text { Time of } \\
\text { concentration (min) }\end{array}$ & Modified & $2.0^{*}$ & -3.5 \\
\hline
\end{tabular}

Table 4 Trend detection results for the parameters in the conceptual urban rainfall-runoff model
619

620

621

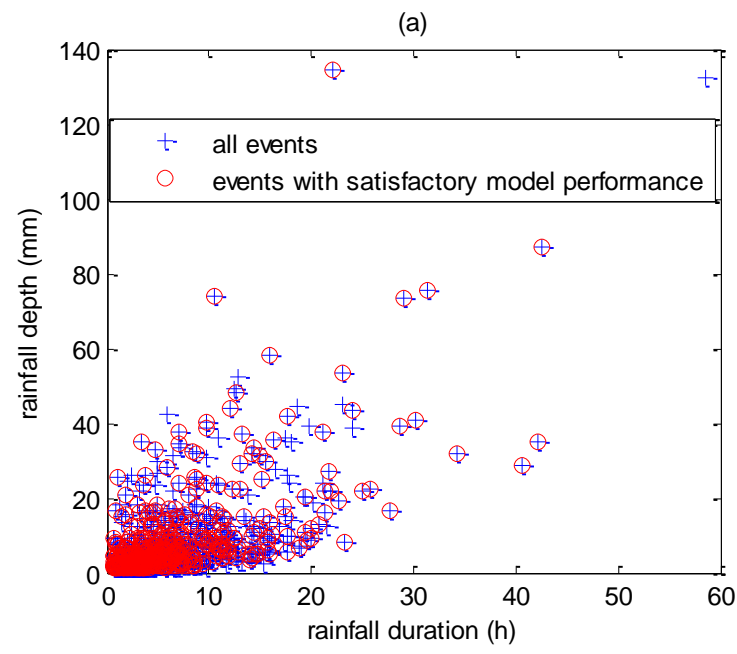


(1a)

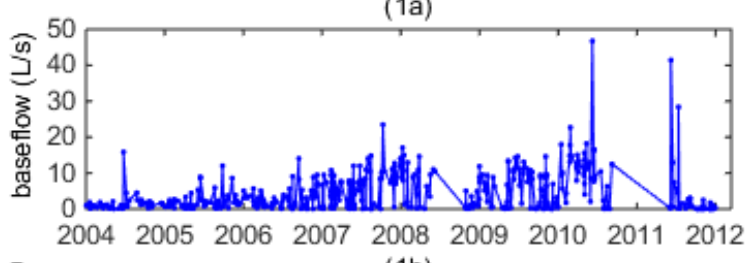

(1b)

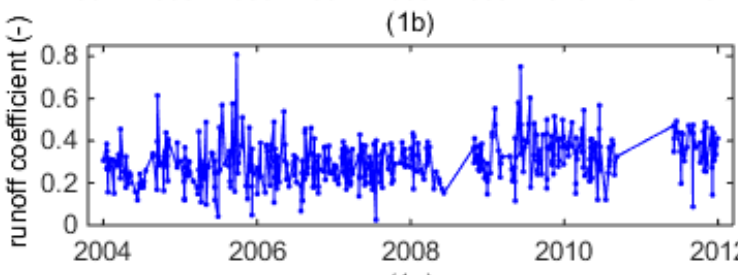

(1c)

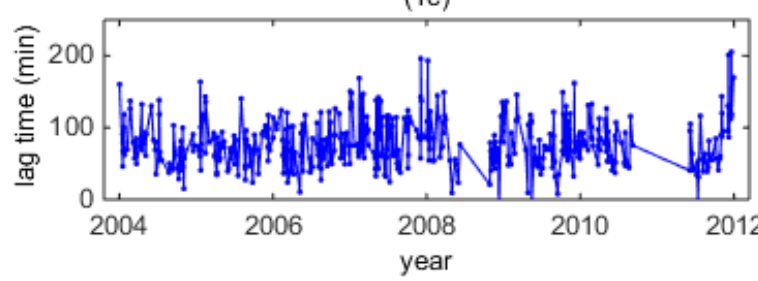

(2a)

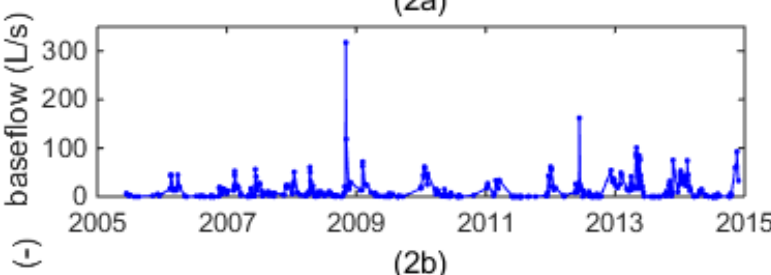

(2b)
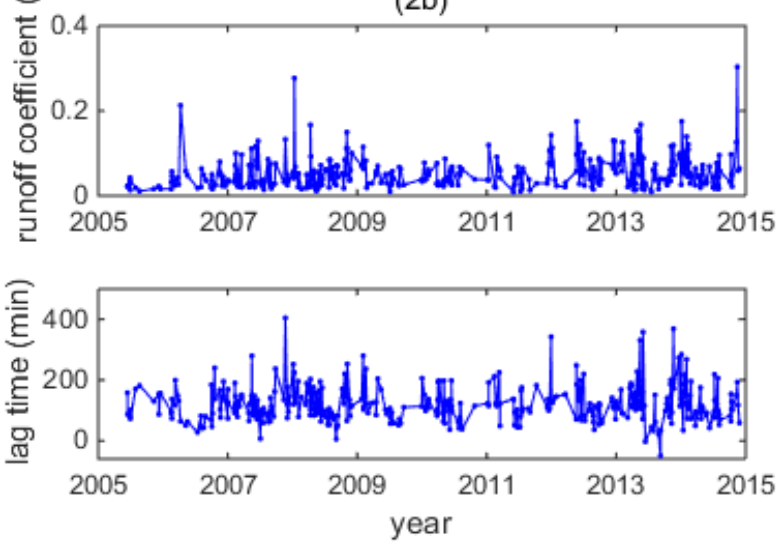

625

Fig. 2 Simple variables in chronological order: (1) Chassieu; (2) La Lechere

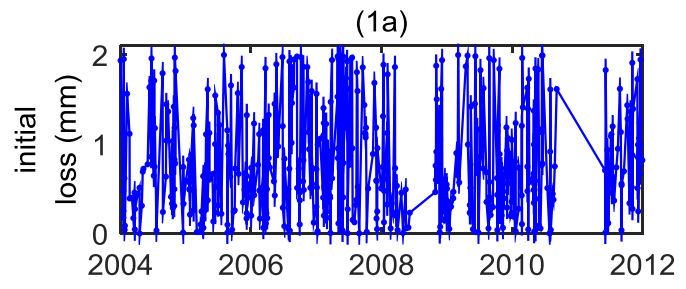

(1b)
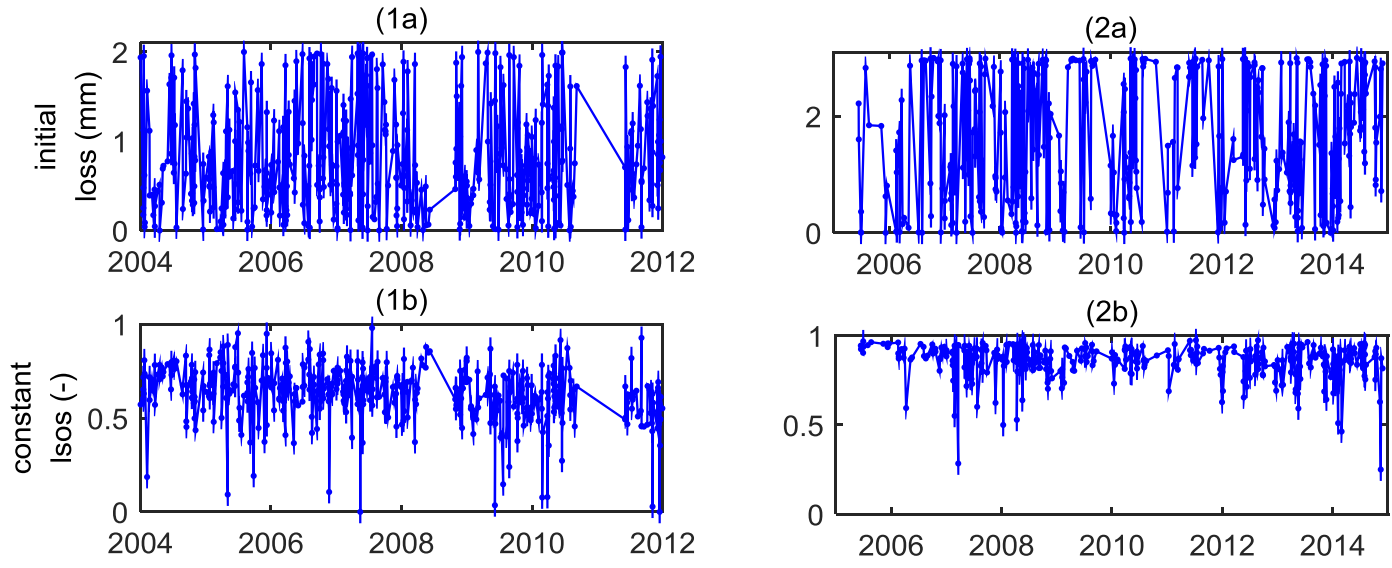

(2b)
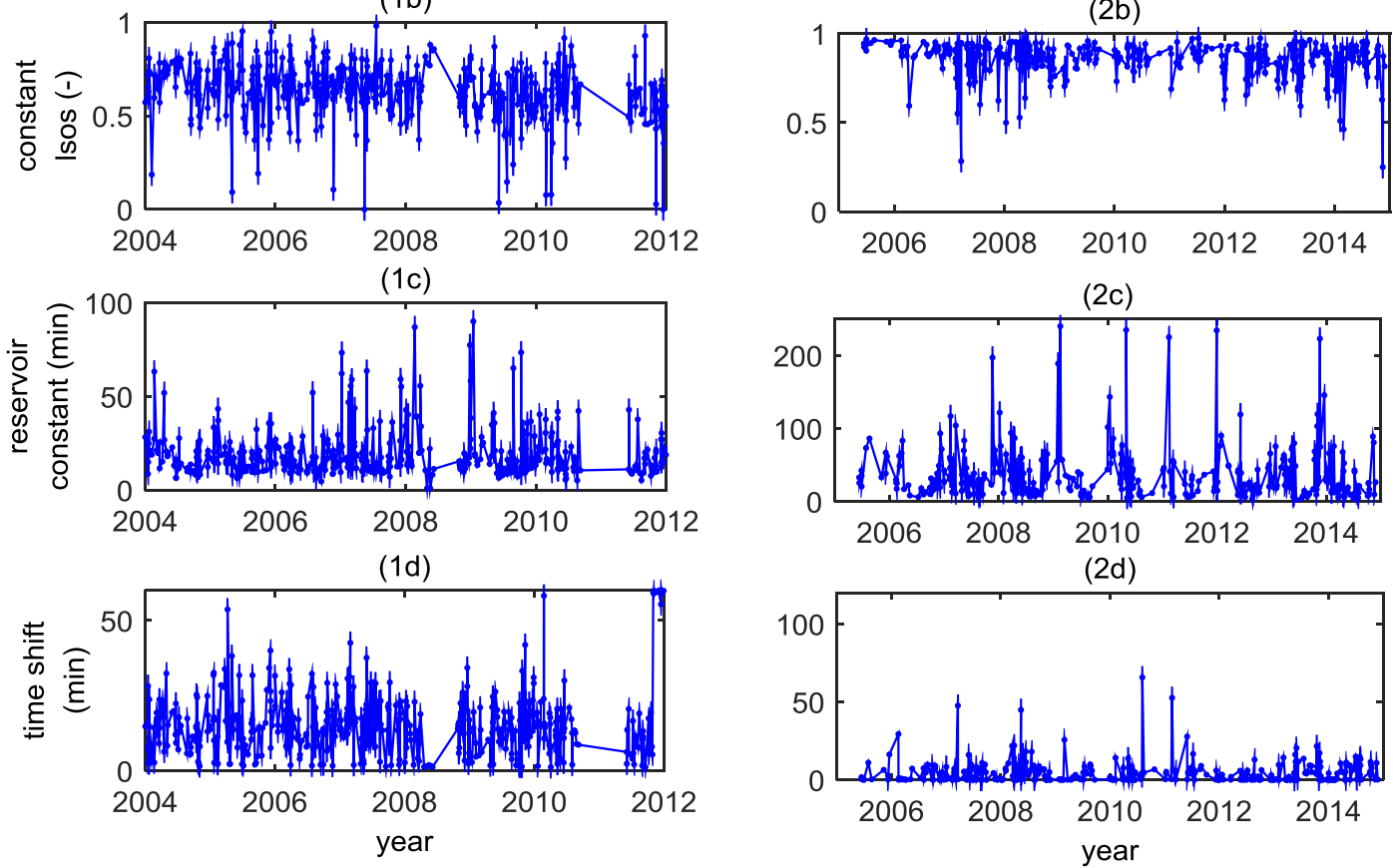

626

627 Fig. 3 Optimal model parameters of conceptual urban rainfall-runoff models using event628 based calibration: (1) Chassieu; (2) La Lechere 

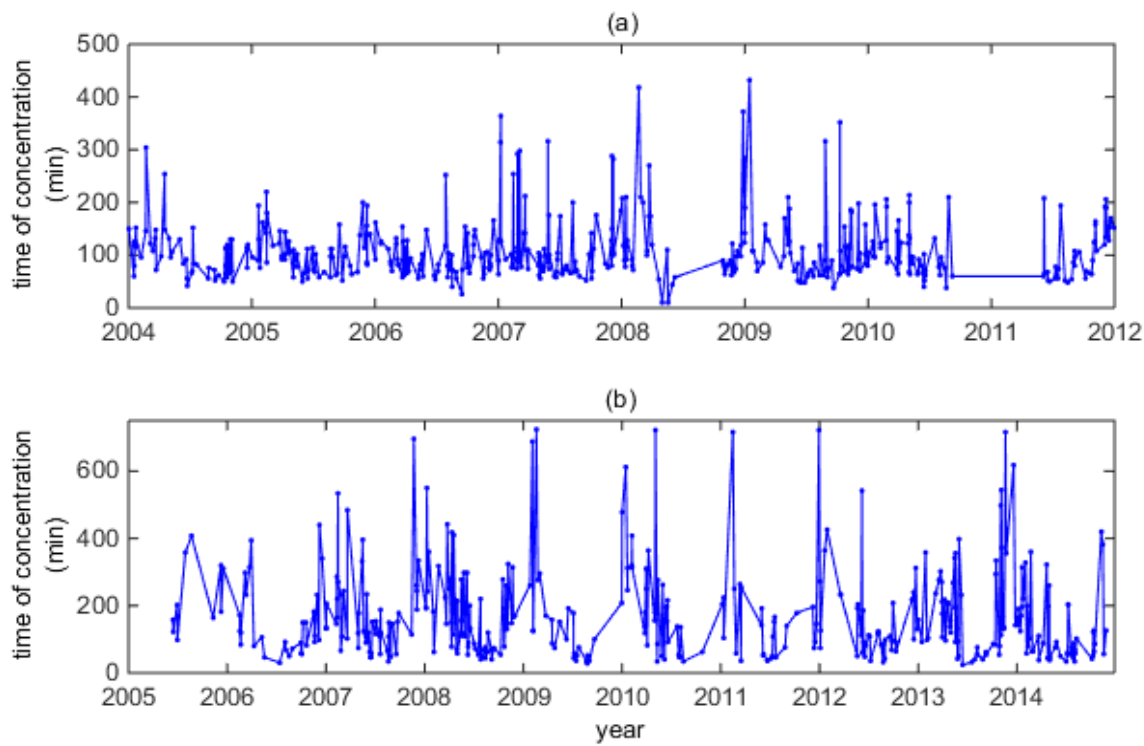

Fig. 4 Time of concentration from calibrated model parameters: (a) Chassieu; (b) La Lechere
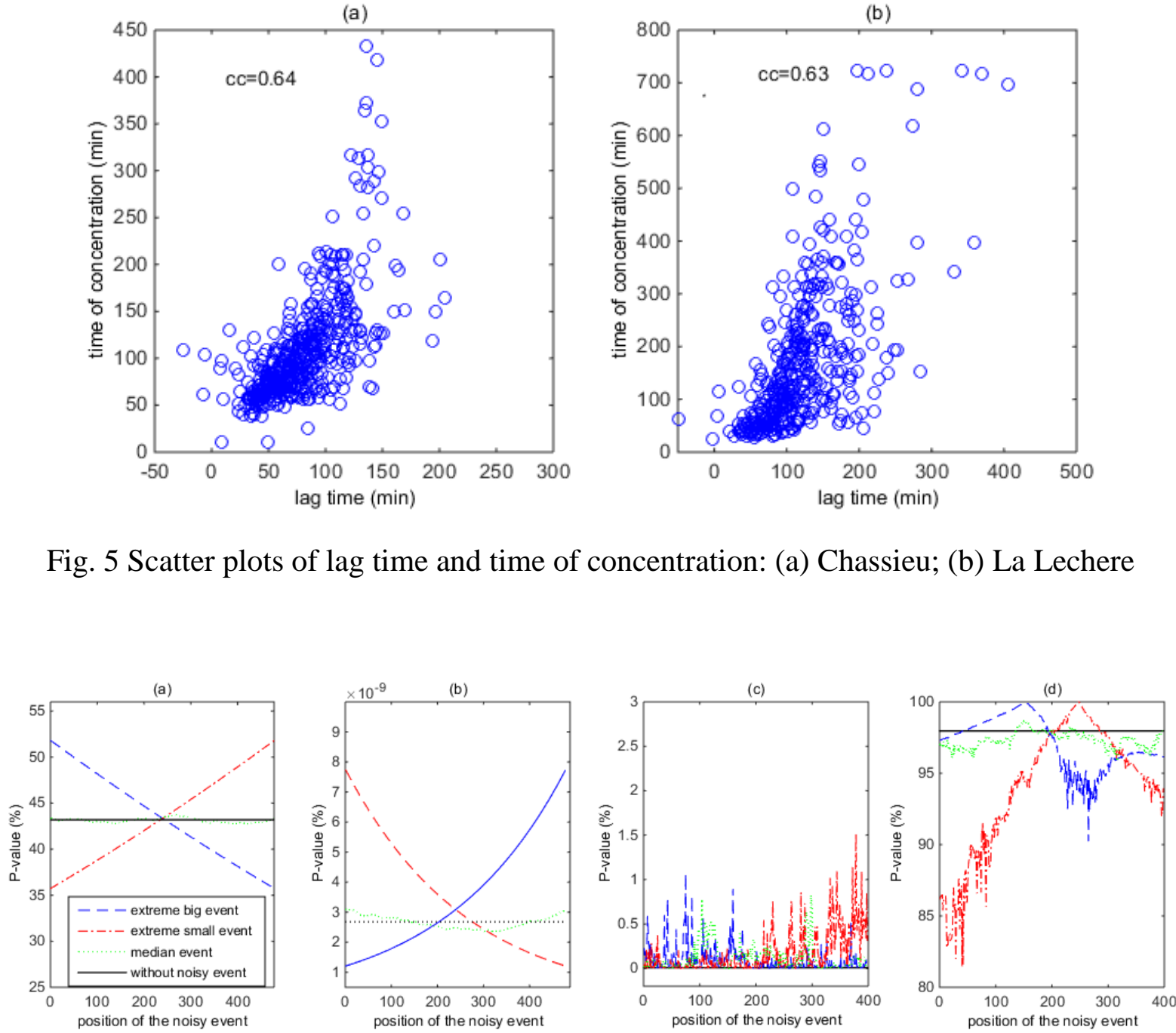

635 Fig. 6 Sensitivity of P-values to one noisy value: (a) the initial loss in Chassieu; (b) the constant loss in Chassieu; (c) the constant loss in La Lechere; (d) the time shift in La Lechere 
Manuscript accepted for publication in Hydrological Processes, December 2016, doi: 10.1002/hyp.11109
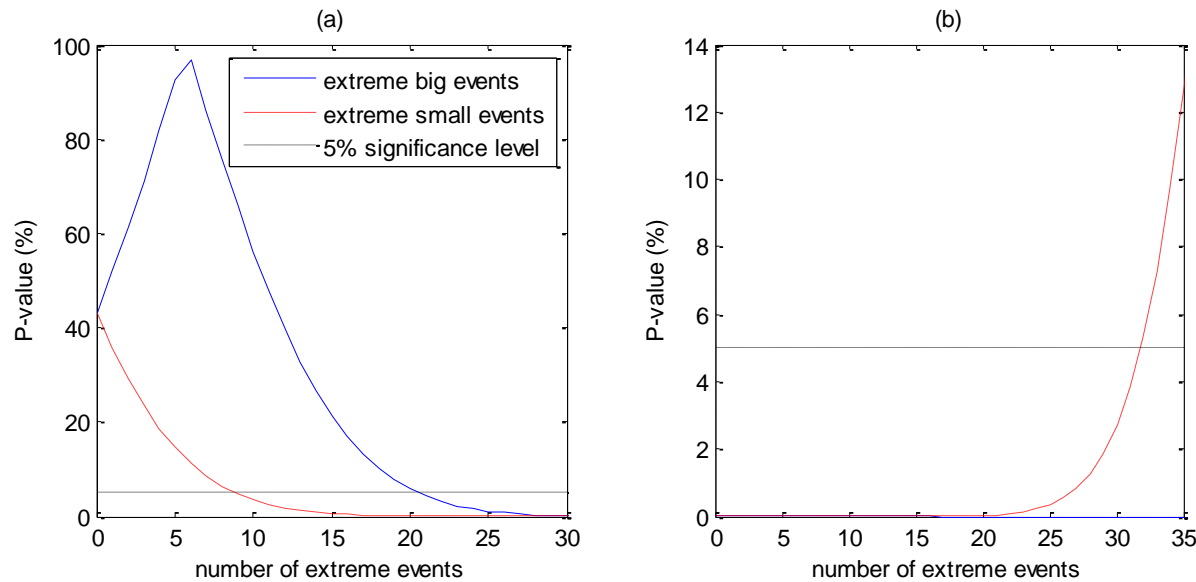

638 Fig. 7 Sensitivity of $P$-values to a number of extreme events introduced in the beginning of

639 data series using the original Mann-Kendall method: (a) the initial loss in Chassieu; (b) the 640 constant loss in Chassieu. 